\title{
Leucobacter chironomi sp. nov., a chromate- resistant bacterium isolated from a chironomid egg mass
}

Correspondence

Malka Halpern

mhalpern@research.haifa.ac.il

\author{
Malka Halpern, ${ }^{1}$ Tamar Shakéd, ${ }^{1}$ Rüdiger Pukall ${ }^{2}$ and Peter Schumann ${ }^{2}$ \\ ${ }^{1}$ Department of Biology Education, Faculty of Science and Science Education, University of Haifa, \\ Oranim, Tivon 36006, Israel \\ ${ }^{2}$ DSMZ - Deutsche Sammlung von Mikroorganismen und Zellkulturen GmbH, Inhoffenstr. 7B, \\ D-38124 Braunschweig, Germany
}

The genus Leucobacter (family Microbacteriaceae) was erected by Takeuchi et al. (1996). All species of the genus are characterized by 2,4-diaminobutyric acid (DAB) as the diagnostic diamino acid in the peptidoglycan. However, there are differences in the amounts of other amino acids in the peptidoglycan. Among members of the genus, $\gamma$ aminobutyric acid has been found only in Leucobacter albus and Leucobacter komagatae. At the time of writing, the genus comprises eight recognized species: L. komagatae (Takeuchi et al., 1996), L. chromiireducens (Morais et al., 2004; Muir \& Tan, 2007), L. aridicollis (Morais et al., 2004), L. albus (Lin et al., 2004), L. alluvii and L. luti (Morais et al., 2006), L. iarius (Somvanshi et al., 2007) and L. tardus (Behrendt et al., 2008).

Strains belonging to the genus Leucobacter occur in a variety of ecological niches such as activated sludge (from a

Abbreviation: DAB, 2,4-diaminobutyric acid.

The GenBank/EMBL/DDBJ accession number for the 16S rRNA gene sequence of strain MM2LB' is EU346911.

An electron micrograph of a negatively stained cell of strain MM2LB and a table detailing the major fatty acid contents of strain MM2LB ${ }^{\top}$ and recognized species of the genus Leucobacter are available with the online version of this paper. treatment plant containing chromium-contaminated wastewater; Morais et al., 2004, 2006), soil (Lin et al., 2004), river sediment (Morais et al., 2006), nematodes (Somvanshi et al., 2007, Muir \& Tan, 2007) and the phyllosphere of potato plants (Behrendt et al., 2008). In the present study, an obligately aerobic, non-motile, Gram-positive, rod-shaped bacterium (strain $\mathrm{MM} 2 \mathrm{LB}^{\mathrm{T}}$ ), isolated from a freshwater insect egg mass, is proposed as representing a novel species of the genus Leucobacter.

Strain MM2LB ${ }^{\mathrm{T}}$ was isolated during the course of studies aimed at identifying culturable bacteria from chironomid (non-biting midge, Chironomidae; Diptera) egg masses. Chironomid egg masses were sampled from Tivon waste stabilization pond in northern Israel, as previously described (Halpern et al., 2007a). To determine the diversity of culturable bacteria in chironomid egg masses, the masses were washed thoroughly with sterile saline (vortexing for $1 \mathrm{~min}$ with five changes of saline) and then their homogenates were diluted and cultured directly on Luria-Bertani (LB) agar (Himedia). More than $10^{4}$ faecal coliforms $\mathrm{ml}^{-1}$ were counted in Tivon waste stabilization pond water samples (Halpern et al., 2004). However, no faecal coliforms were isolated from the egg mass when MacConkey agar, a selective medium for Escherichia coli, 
was used. This indicated that the egg masses had been rinsed thoroughly and that the novel bacterial isolate was tightly bound to the egg mass.

Strain MM2LB ${ }^{\mathrm{T}}$ was isolated in July 2006 from a chironomid egg mass, cultured on LB agar and incubated at $30{ }^{\circ} \mathrm{C}$ for $48 \mathrm{~h}$ in the dark. Two other novel species that were isolated from chironomid egg masses in a previous study were recently characterized as Oceanobacillus chironomi (Raats \& Halpern, 2007) and Rheinheimera chironomi (Halpern et al., 2007b). The exact taxonomic position of strain MM2LB ${ }^{\mathrm{T}}$ was determined by means of a polyphasic approach that included phenotypic characterization and phylogenetic analysis based on 16S rRNA gene sequences.

Universal bacterial primers $8 \mathrm{f}$ and 1512r (Felske et al., 1997) were used to amplify internal fragments of the $16 \mathrm{~S}$ rRNA gene of strain MM2LB ${ }^{\mathrm{T}}$. Purified PCR products were sequenced with primers $8 \mathrm{f}, 534 \mathrm{r}, 968 \mathrm{f}$ and $1512 \mathrm{r}$ as described in detail by Raats \& Halpern (2007). This resulted in a sequence of approximately $1500 \mathrm{bp}$. Identification of phylogenetic neighbours and calculation of pairwise $16 \mathrm{~S}$ rRNA gene sequence similarity were performed by using the EzTaxon server (http://www.eztaxon.org/; Chun et al., 2007). Phylogenetic and molecular evolutionary analyses were conducted by using MEGA version 4 (Tamura et al., 2007). Strain MM2LB ${ }^{T}$ showed highest levels of $16 \mathrm{~S}$ rRNA gene sequence similarity with $L$. aridicollis CIP $108388^{\mathrm{T}}$ (97.1\%), L. komagatae IFO $15245^{\mathrm{T}}$ $(97.0 \%)$ and the type strains of other recognized Leucobacter species (96.8-96.4\%). In the neighbour-joining tree based on 16S rRNA gene sequences, strain MM2LB ${ }^{\mathrm{T}}$ formed a distinct branch within the radiation encompassing the genus Leucobacter (Fig. 1). Levels of $16 \mathrm{~S}$ rRNA gene sequence similarity between strain $M M 2 L^{T}$ and the type strains of representative members of other genera were below $94.9 \%$. The data from 16S rRNA gene sequence analysis thus suggest that strain $\mathrm{MM} 2 \mathrm{LB}^{\mathrm{T}}$ represents a novel species within the genus Leucobacter (Stackebrandt \& Goebel, 1994; Stackebrandt \& Ebers, 2006).
For electron microscopy, bacteria on LB agar medium were suspended in saline. The samples were adhered to a carbon-coated grid, stained with $2 \%$ uranyl acetate and photographed under a JEM-1200EX electron microscope (JEOL). Electron microscopy showed that the cells were rods measuring $0.5-0.75 \mu \mathrm{m}$ in width and $0.95-1.4 \mu \mathrm{m}$ in length (see Supplementary Fig. S1 in IJSEM Online).

For phenotypic characterization, LB agar containing $0.5 \%$ $\mathrm{NaCl}$ was used as the basal growth medium (except for determination of salt tolerance where $\mathrm{LB}$ agar lacking $\mathrm{NaCl}$ was used). Salt tolerance was determined at $30{ }^{\circ} \mathrm{C}$ on $\mathrm{LB}$ agar containing $0-10 \%(\mathrm{w} / \mathrm{v}) \mathrm{NaCl}$ at $1.0 \%$ intervals. Growth at 5,10,14, 17, 25,30,33,37, 40 and $45{ }^{\circ} \mathrm{C}$ was measured on LB agar. The $\mathrm{pH}$ range for growth was determined by using LB broth adjusted to $\mathrm{pH} 4.0-8.0$ at $2.0 \mathrm{pH}$ unit intervals. The $\mathrm{pH}$ was adjusted prior to sterilization by the addition of $\mathrm{HCl}$ or $\mathrm{NaOH}$ and was measured again following sterilization. For determination of growth on alkaline medium, LB broth was adjusted to $\mathrm{pH} 9.0,9.5$ and 10.0 with $0.1 \mathrm{M} \mathrm{Na}_{2} \mathrm{CO}_{3}$ or $0.1 \mathrm{M}$ $\mathrm{NaHCO}_{3}$ and then filtered through a $0.2 \mu \mathrm{m}$ pore size filter (Corning) to obtain a sterilized medium. Growth under anaerobic conditions was determined after incubation in an anaerobic chamber on LB agar supplemented with $0.5 \%(\mathrm{w} / \mathrm{v})$ glucose or $0.1 \%(\mathrm{w} / \mathrm{v})$ potassium nitrate. Growth on marine, MacConkey and cetrimide agars (Himedia) was determined after $48 \mathrm{~h}$ incubation at $30{ }^{\circ} \mathrm{C}$. Biochemical tests were performed by using API 20E, API 20NE, API 50CH and API ZYM identification systems (bioMérieux), according to the manufacturer's instructions, except that the incubation temperature was $30{ }^{\circ} \mathrm{C}$. Substrate utilization was analysed by using Biolog GP2 microplates according to the manufacturer's instructions (release 3.50, version DE). The plates were incubated for $24 \mathrm{~h}$ at $30{ }^{\circ} \mathrm{C}$ before being read with the Microlog plate reader. Wells that changed colour to purple were marked as positive for metabolic activity. Catalase activity was determined based on bubble production in a $3 \%(\mathrm{v} / \mathrm{v})$ hydrogen peroxide solution. Oxidase activity was deter-

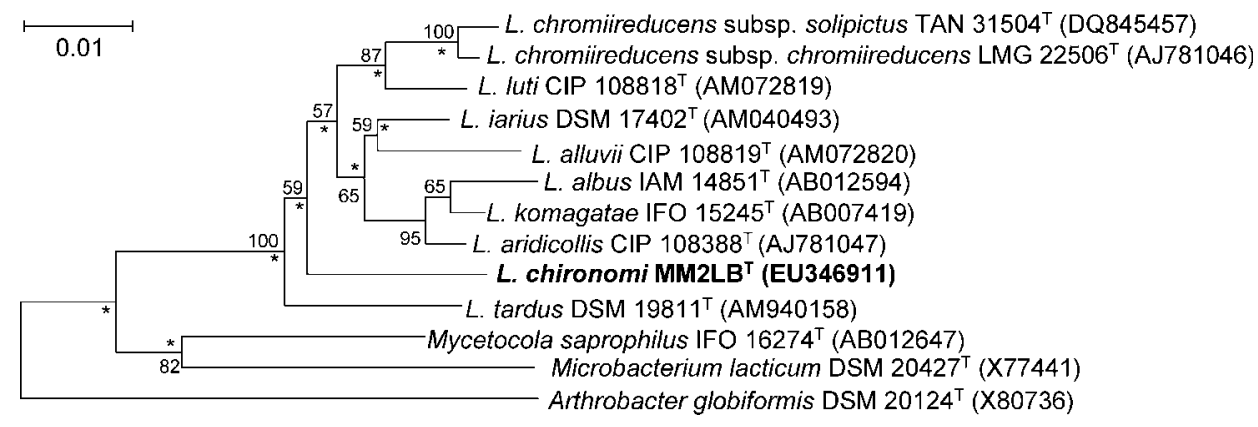

Fig. 1. Neighbour-joining phylogenetic tree based on $16 \mathrm{~S}$ rRNA gene sequences obtained from strain MM2LB ${ }^{\top}$ and the type strains of related species. Bootstrap values (>50\%) based on 1000 replicates are indicated at branch points. Arthrobacter globiformis DSM $20124^{\top}$ was used as an outgroup. Asterisks indicate branches of the tree that were also formed by using the maximum-parsimony method. Bar, 0.01 substitutions per nucleotide position. 
mined by using $1 \% N, N, N^{\prime}, N^{\prime}$-tetramethyl-p-phenylenediamine dihydrochloride (T3134; Sigma-Aldrich). The phenotypic traits of the new isolate are detailed in the species description below and in Table 1 .

For cellular fatty acid analysis, strain $\mathrm{MM}_{2} \mathrm{LB}^{\mathrm{T}}$ was cultured on trypticase soy agar (Difco) for $24 \mathrm{~h}$ at $28{ }^{\circ} \mathrm{C}$ and the fatty acids were then extracted and methylated (Ben-Ze'ev et al., 2005). Fatty acid methyl esters were analysed by GC by using the MIDI/Hewlett Packard microbial identification system (Analytical Services Inc.). The major fatty acids $(>10 \%$ of the total) of strain $\mathrm{MM}_{2} \mathrm{LB}^{\mathrm{T}}$ were anteiso- $\mathrm{C}_{15: 0}(47.0 \%)$, anteiso- $\mathrm{C}_{17: 0}$ $(23.9 \%)$ and iso- $\mathrm{C}_{16: 0}$ (22.9\%) (see Supplementary Table S1 in IJSEM Online).

The composition of the cell-wall peptidoglycan is a useful diagnostic tool for characterizing novel species belonging to the family Microbacteriaceae. For analysis, purified peptidoglycan preparations were obtained after disruption of cells by shaking with glass beads and subsequent trypsin digestion, according to the method of Schleifer (1985). The amino acids and peptides in the cell-wall hydrolysates were analysed by two-dimensional ascending TLC on cellulose plates by using the solvent systems described by Schleifer (1985). The molar ratios of the amino acids were determined by GC (GC 14A; Shimadzu) and GC-MS (320-MS Quadrupole GC/MS; Varian) of N-heptafluorobutyryl amino acid isobutyl esters (MacKenzie, 1987; Groth et al., 1996). The hydrolysate ( $\left.4 \mathrm{M} \mathrm{HCl}, 100{ }^{\circ} \mathrm{C}, 16 \mathrm{~h}\right)$ of the purified peptidoglycan of strain $\mathrm{MM} 2 \mathrm{LB}^{\mathrm{T}}$ contained the amino acids alanine, glycine, threonine, $\mathrm{DAB}$ and glutamic acid in a molar ratio of approximately $2.5: 1.2: 0.9: 0.5: 1.0$, respectively. $\gamma$-Aminobutyric acid was also present but could not be quantified (Table 1). Strain MM2LB ${ }^{\mathrm{T}}$ possessed a B-type cross-linked peptidoglycan (Schleifer \& Kandler, 1972).

Isoprenoid quinone analysis of strain $\mathrm{MM} 2 \mathrm{LB}^{\mathrm{T}}$ was performed by HPLC as described by Groth et al. (1996). Strain MM2LB ${ }^{\mathrm{T}}$ contained menaquinones MK-11, MK-10 and MK-12 in a molar ratio of approximately $85: 9: 6$, respectively (Table 1 ).

As several species of the genus Leucobacter (L. chromiireducens, $L$. aridicollis, L. komagatae, L. luti and L. alluvii) showed resistance to chromate, tolerance to chromium was examined by culturing strain $\mathrm{MM} 2 \mathrm{LB}^{\mathrm{T}}$ in $\mathrm{LB}$ broth supplemented with $\mathrm{K}_{2} \mathrm{CrO}_{4}$ at final concentrations of 1 , $3,4,5,6,8,10,12,16,18$ and $20 \mathrm{mM} \mathrm{Cr}(\mathrm{VI})$. Cells were incubated at $30{ }^{\circ} \mathrm{C}$ for $48 \mathrm{~h}$. Strain MM2LB ${ }^{\mathrm{T}}$ grew in the presence of up to $18 \mathrm{mM} \mathrm{Cr}(\mathrm{VI})$.

The new isolate shared the main characteristics of strains of species of the genus Leucobacter, namely non-motile, rod-shaped, catalase-positive cells, anteiso- $\mathrm{C}_{15: 0}$, iso$\mathrm{C}_{16: 0}$ and anteiso- $\mathrm{C}_{17: 0}$ as the dominant fatty acids, MK-11 as the major menaquinone, and DAB, alanine, glycine and glutamic acid in a B-type cross-linked peptidoglycan. However, strain $M M 2 \mathrm{LB}^{\mathrm{T}}$ differed from recognized Leucobacter species based on several phenotypic traits (see Table 1). Strain MM2LB ${ }^{\mathrm{T}}$ contained $\gamma$ aminobutyric acid, which has been described only in $L$. albus and L. komagatae among members of the genus Leucobacter. On the basis of phenotypic characterization and 16S rRNA gene sequence phylogenetic analysis, we suggest that strain MM2LB ${ }^{\mathrm{T}}$ represents a novel species of the genus Leucobacter, for which the name Leucobacter chironomi sp. nov. is proposed.

\section{Description of Leucobacter chironomi sp. nov.}

Leucobacter chironomi [chi.ro' no.mi. N.L. gen. n. chironomi of Chironomus, named after the non-biting midge insect of the genus Chironomus (Chironomidae: Diptera) from which the type strain was isolated].

Cells are aerobic, Gram-positive, non-motile rods measuring $0.5-0.75 \mu \mathrm{m}$ in width and $0.95-1.4 \mu \mathrm{m}$ in length. Cells occur singly. After $48 \mathrm{~h}$ incubation on LB agar at $30{ }^{\circ} \mathrm{C}$, colonies are opaque, circular, with entire margins and yellow-coloured. Growth is not observed under anaerobic conditions even after 8 days incubation. Growth is observed after $48 \mathrm{~h}$ incubation at $17-37{ }^{\circ} \mathrm{C}$ (optimum $30{ }^{\circ} \mathrm{C}$ ), in the presence of $0-7.0 \% \mathrm{NaCl}$ (optimum $0-1.0 \% \mathrm{NaCl}$ ) and at $\mathrm{pH} 4.0-9.5$ (optimum $\mathrm{pH}$ 6.0-8.0). Good growth occurs on marine agar after $48 \mathrm{~h}$ incubation. Growth is not observed on MacConkey or cetrimide agars. Oxidase reaction is negative; catalase reaction is weakly positive. Although the type strain was not isolated from a chromium-enriched environment, it is able to grow in the presence of up to $18.0 \mathrm{mM} \mathrm{Cr}(\mathrm{VI})$. On API $50 \mathrm{CH}$ strips incubated for $48 \mathrm{~h}$ at $30{ }^{\circ} \mathrm{C}$, acid is not produced from any of the substrates tested. On API 20NE strips incubated for $48 \mathrm{~h}$ at $30^{\circ} \mathrm{C}$, all the results are negative. The following results are obtained from API $20 \mathrm{E}$ strips after $48 \mathrm{~h}$ incubation at $30{ }^{\circ} \mathrm{C}$ : acetoin is produced; nitrate is reduced to nitrogen; $\mathrm{H}_{2} \mathrm{~S}$ and indole are not produced; urea and gelatin are not hydrolysed; citrate is not utilized; and $\beta$-galactosidase, arginine dihydrolase, lysine decarboxylase, ornithine decarboxylase and tryptophan deaminase activities are absent. Putrescine and glycerol are utilized in the Biolog test plates. Cell-wall amino acids are alanine, glycine, threonine, DAB, $\gamma$ aminobutyric acid and glutamic acid. Has a B-type crosslinked peptidoglycan. The major menaquinone is MK-11; MK-10 and MK-12 occur in minor amounts. The dominant cellular fatty acids are anteiso- $\mathrm{C}_{15: 0}$, anteiso$\mathrm{C}_{17: 0}$ and iso- $\mathrm{C}_{16: 0}$. The following fatty acids are present as minor components: $C_{16: 0}, C_{14: 0}$ and iso- $C_{15: 0}$.

The type strain, MM2LB ${ }^{\mathrm{T}}\left(=\mathrm{LMG} 24399^{\mathrm{T}}=\right.$ DSM $\left.19883^{\mathrm{T}}\right)$, was isolated from a chironomid egg mass in Israel.

\section{Acknowledgements}

Strain MM2LB ${ }^{\mathrm{T}}$ was isolated by Maya Ben-Zion and Michal BenHarush during the course of a microbial ecology workshop. 
Table 1. Differential phenotypic characteristics between strain MM2LB ${ }^{\top}$ and recognized species of the genus Leucobacter

Strains: 1, MM2LB ${ }^{\mathrm{T}}$; 2, L. albus DSM $17379^{\mathrm{T}} ; 3$, L. chromiireducens subsp. chromiireducens DSM $17381^{\mathrm{T}}$; 4, L. aridicollis DSM $17380^{\mathrm{T}}$; 5 , L. komagatae DSM $8803^{\mathrm{T}}$; 6, L. luti CIP $108818^{\mathrm{T}}$; 7, L. alluvii CIP $108819^{\mathrm{T}}$; 8. L. iarius DSM $17402^{\mathrm{T}}$; 9, L. tardus DSM 19811 ${ }^{\mathrm{T}}$. Results of acid production from various substrates were determined by using an API 50CH test panel with medium E and were scored after 2 days. All strains were negative for all other substrates provided on the API 50CH test panel. Data for reference taxa were obtained from Takeuchi et al. (1996), Lin et al. (2004), Morais et al. (2004), Muir \& Tan (2007), Somvanshi et al. (2007) and Behrendt et al. (2008). +, Positive; -, negative; w, weakly positive; $\mathrm{NA}$, data not available; $+1-$, different reactions reported.

\begin{tabular}{|c|c|c|c|c|c|c|c|c|c|}
\hline Characteristic & 1 & 2 & 3 & 4 & 5 & 6 & 7 & 8 & 9 \\
\hline Colony pigmentation & Yellow & White & Cream & Cream & Whitish brown & Cream & Cream & White & Yellow \\
\hline Urease & - & - & + & + & + & + & + & - & - \\
\hline Gelatinase & - & $\mathrm{NA}$ & - & - & + & - & + & - & - \\
\hline $\mathrm{pH}$ optimum & $6-8$ & NA & 7 & $7-8$ & $7-9$ & $7-9$ & $7-8$ & NA & NA \\
\hline \multicolumn{10}{|l|}{ Growth at: } \\
\hline $4{ }^{\circ} \mathrm{C}$ & - & NA & - & - & + & + & + & - & - \\
\hline $37{ }^{\circ} \mathrm{C}$ & + & NA & + & + & - & - & + & + & - \\
\hline Optimal temperature $\left({ }^{\circ} \mathrm{C}\right)$ & 30 & 30 & 28 & 28 & 28 & 25 & 30 & 30 & $21-30$ \\
\hline \multicolumn{10}{|l|}{ Growth in the presence of: } \\
\hline $7 \% \mathrm{NaCl}$ & + & NA & + & + & - & + & + & + & NA \\
\hline $10 \% \mathrm{NaCl}$ & - & NA & - & + & - & - & - & - & NA \\
\hline \multicolumn{10}{|c|}{ Amino acids in the cell wall (molar ratios) } \\
\hline $\mathrm{DAB}^{\star}$ & 0.5 & 0.8 & 0.9 & 0.5 & 0.8 & 0.5 & 0.5 & 0.5 & 0.5 \\
\hline Alanine & 2.5 & 1.8 & 1.9 & 2.0 & 1.9 & 0.5 & 2.4 & 1.5 & 3.2 \\
\hline Glycine & 1.2 & 1.1 & 1.3 & 1.1 & 0.9 & 0.3 & 1.2 & 0.9 & 2.1 \\
\hline Glutamic acid & 1.0 & 1.0 & 1.0 & 1.0 & 1.0 & 1.0 & 1.0 & 1.0 & 1.0 \\
\hline$\gamma$-Aminobutyric acid & $+\dagger$ & 0.7 & - & - & 0.7 & - & - & - & - \\
\hline Threonine & 0.9 & - & 0.7 & - & - & 0.6 & 0.7 & 0.7 & - \\
\hline \multicolumn{10}{|l|}{ Menaquinone(s) (MK-) } \\
\hline Major amounts & 11 & 11 & 11 & 11 & 11 & 11 & 11 & 11 & $10 ; 11$ \\
\hline Minor amounts & $10 ; 12$ & $12 ; 9$ & 10 & 10 & $10 ; 12$ & 10 & 10 & $10 ; 9 ; 12$ & 9 \\
\hline \multicolumn{10}{|l|}{ Acid production from (API $50 \mathrm{CH})$ : } \\
\hline$N$-Acetylglucosamine & - & - & - & - & - & - & - & + & - \\
\hline D-Adonitol & - & - & - & - & $\mathrm{w}$ & - & - & - & - \\
\hline D-Arabinose & - & $\mathrm{W}$ & - & - & - & - & - & - & - \\
\hline L-Arabinose & - & - & - & - & $\mathrm{w}$ & - & - & - & - \\
\hline L-Fucose & - & + & - & - & - & - & - & - & - \\
\hline Fructose & - & - & - & - & - & - & - & + & + \\
\hline Glycerol & - & $\mathrm{W}$ & - & - & + & - & - & + & - \\
\hline Inositol & - & - & - & - & - & $\mathrm{W}$ & - & $\mathrm{W}$ & - \\
\hline 5-Ketogluconate & - & - & - & - & - & - & - & $\mathrm{w}$ & - \\
\hline Melezitose & - & - & - & - & - & - & - & - & + \\
\hline Salicin & - & - & - & - & - & - & - & $\mathrm{W}$ & - \\
\hline Trehalose & - & + & - & - & - & - & - & - & - \\
\hline Raffinose & - & - & - & - & - & - & - & - & + \\
\hline L-Rhamnose & - & - & - & - & - & $\mathrm{w}$ & - & - & + \\
\hline Ribose & - & + & - & - & + & + & - & + & - \\
\hline \multicolumn{10}{|c|}{ Utilization of (Biolog GP2 micro plates): $\ddagger$} \\
\hline$N$-Acetyl-D-glucosamine & - & - & - & - & - & - & - & + & - \\
\hline$N$-Acetyl L-glutamic acid & - & + & - & - & - & $\mathrm{w}$ & - & - & + \\
\hline Adenosine & - & $\mathrm{W}$ & + & + & - & - & + & + & + \\
\hline Adenosine $5^{\prime}$-monophosphate & - & - & - & + & - & - & - & $\mathrm{w}$ & - \\
\hline L-Alaninamide & - & + & + & + & + & - & + & + & + \\
\hline L-Alanine & - & $\mathrm{W}$ & + & + & - & + & + & $\mathrm{w}$ & - \\
\hline L-Alanyl glycine & - & + & $+1-$ & + & - & - & + & - & - \\
\hline L-Arabinose & - & - & - & - & - & - & - & - & + \\
\hline L-Asparagine & - & + & - & + & - & - & - & - & - \\
\hline 2,3-Butanediol & - & - & - & - & - & - & - & - & + \\
\hline 2'-Deoxyadenosine & - & + & + & + & + & $\mathrm{w}$ & - & - & + \\
\hline Dextrin & - & - & - & - & - & - & + & - & - \\
\hline
\end{tabular}


Table 1. cont.

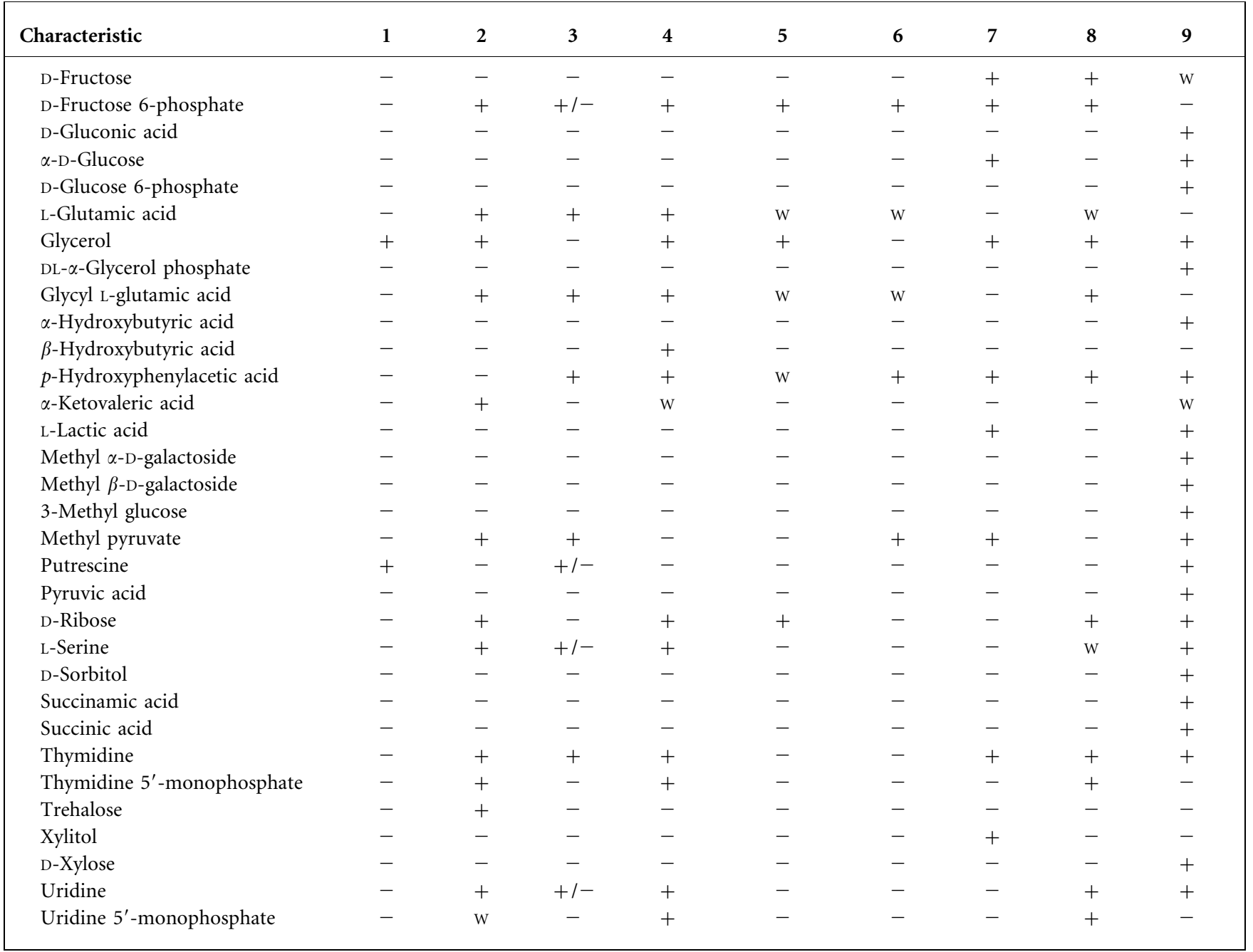

${ }^{\star} \mathrm{DAB}, 2$,4-diaminobutyric acid.

$\dagger \gamma$-Aminobutyric acid is present but could not be quantified.

¥Data for reference species from Muir \& Tan (2007), Somvanshi et al. (2007) and Behrendt et al. (2008).

\section{References}

Behrendt, U., Ulrich, A. \& Schumann, P. (2008). Description of Leucobacter tardus sp. nov., isolated from the phyllosphere of Solanum tuberosum L. Int J Syst Evol Microbiol 58, 2574-2578.

Ben-Ze'ev, I. S., Levy, E., Eilam, T. \& Anikster, Y. (2005). Whole-cell fatty acid profiles - a tool for species and subspecies classification in the Puccinia recondita complex. J Plant Pathol 87, 187-197.

Chun, J., Lee, J.-H., Jung, Y., Kim, M., Kim, S., Kim, B. K. \& Lim, Y. W. (2007). EzTaxon: a web-based tool for the identification of prokaryotes based on $16 \mathrm{~S}$ ribosomal RNA gene sequences. Int J Syst Evol Microbiol 57, 2259-2261.

Felske, A., Rheims, H., Wolterink, A., Stackebrandt, E. \& Akkermans, A. D. (1997). Ribosome analysis reveals prominent activity of an uncultured member of the class Actinobacteria in grassland soils. Microbiology 143, 2983-2989.

Groth, I., Schumann, P., Weiss, N., Martin, K. \& Rainey, F. A. (1996). Agrococcus jenensis gen. nov., sp. nov., a new genus of actinomycetes with diaminobutyric acid in the cell wall. Int J Syst Bacteriol 46, 234239.

Halpern, M., Broza, Y. B., Mittler, S., Arakawa, E. \& Broza, M. (2004). Chironomid egg masses as a natural reservoir of Vibrio cholerae non-O1 and non-O139 in freshwater habitats. Microb Ecol 47, 341349.

Halpern, M., Landsberg, O., Raats, D. \& Rosenberg, E. (2007a). Culturable and VBNC Vibrio cholerae; interactions with chironomid egg masses and their bacterial population. Microb Ecol 53, 285-293.

Halpern, M., Senderovich, Y. \& Snir, S. (2007b). Rheinheimera chironomi sp. nov., isolated from a chironomid (Diptera; Chironomidae) egg mass. Int J Syst Evol Microbiol 57, 1872-1875.

Lin, Y.-C., Uemori, K., de Briel, D. A., Arunpairojana, V. \& Yokota, A. (2004). Zimmermannella helvola gen. nov., sp. nov., Zimmermannella alba sp. nov., Zimmermannella bifida sp. nov., Zimmermannella faecalis sp. nov. and Leucobacter albus sp. nov., novel members of the family Microbacteriaceae. Int J Syst Evol Microbiol 54, 16691676. 
MacKenzie, S. L. (1987). Gas chromatographic analysis of amino acids as the $N$-heptafluorobutyryl isobutyl esters. J Assoc Off Anal Chem 70, 151-160.

Morais, P. V., Francisco, R., Branco, R., Chung, A. P. \& da Costa, M. S. (2004). Leucobacter chromiireducens sp. nov., and Leucobacter aridicollis sp. nov., two new species isolated from a chromium contaminated environment. Syst Appl Microbiol 27, 646-652.

Morais, P. V., Paulo, C., Francisco, R., Branco, R., Chung, A. P. \& da Costa, M. S. (2006). Leucobacter luti sp. nov., and Leucobacter alluvii sp. nov., two new species of the genus Leucobacter isolated under chromium stress. Syst Appl Microbiol 29, 414-421.

Muir, R. E. \& Tan, M. V. (2007). Leucobacter chromiireducens subsp. solipictus subsp. nov., a pigmented bacterium isolated from the nematode Caenorhabditis elegans, and emended description of $L$. chromiireducens. Int J Syst Evol Microbiol 57, 2770-2776.

Raats, D. \& Halpern, M. (2007). Oceanobacillus chironomi sp. nov., a halotolerant and facultative alkaliphilic species isolated from a chironomid egg mass. Int J Syst Evol Microbiol 57, 255-259.

Schleifer, K. H. (1985). Analysis of the chemical composition and primary structure of murein. Methods Microbiol 18, 123-156.
Schleifer, K. H. \& Kandler, O. (1972). Peptidoglycan types of bacterial cell walls and their taxonomic implications. Bacteriol Rev 36, 407-477.

Somvanshi, V. S., Lang, E., Schumann, P., Pukall, R., Kroppenstedt, R. M., Ganguly, S. \& Stackebrandt, E. (2007). Leucobacter iarius sp. nov., in the family Microbacteriaceae. Int J Syst Evol Microbiol 57, 682686.

Stackebrandt, E. \& Ebers, J. (2006). Taxonomic parameters revisited: tarnished gold standards. Microbiol Today 33, 152-155.

Stackebrandt, E. \& Goebel, B. M. (1994). Taxonomic note: a place for DNA-DNA reassociation and $16 \mathrm{~S}$ rRNA sequence analysis in the present species definition in bacteriology. Int J Syst Bacteriol 44, 846849.

Takeuchi, M., Weiss, N., Schumann, P. \& Yokota, A. (1996). Leucobacter komagatae gen. nov., sp. nov., a new aerobic grampositive, nonsporulating rod with 2,4-diaminobutyric acid in the cell wall. Int J Syst Bacteriol 46, 967-971.

Tamura, K., Dudley, J., Nei, M. \& Kumar, S. (2007). MEGA4: molecular evolutionary genetics analysis (MEGA) software version 4.0. Mol Biol Evol 24, 1596-1599. 